\title{
Effect of food intake on myocardial performance index
}

\author{
Ylva Gårdinger ${ }^{1,2^{*}}$ (D) Anna Dieden ${ }^{1}$, Joanna Hlebowicz ${ }^{3}$, Ola Björgell² and Magnus Dencker ${ }^{1}$
}

\begin{abstract}
Background: Myocardial performance index (MPI) has been investigated in a variety of populations, but the effect of food intake has not been evaluated. We assessed whether myocardial performance index is affected by food intake in healthy subjects.

Methods: Twenty-three healthy subjects aged $25.6 \pm 4.5$ years were investigated. MPI was measured before, $30 \mathrm{~min}$ after, and 110 min after a standardized meal.

Results: MPI decreased significantly $(P<0.05)$ from fasting values $30 \mathrm{~min}$ after the meal, and had almost returned to baseline after $110 \mathrm{~min}$. MPI decreased from $0.28 \pm 0.06$ (fasting) to $0.20 \pm 0.0730 \mathrm{~min}$ after eating. At $110 \mathrm{~min}$ after eating the index value was almost back to the baseline value $0.26 \pm 0.06 .(P=0.15)$.

Conclusions: This study shows that myocardial performance index is affected by food intake in healthy subjects.

Keywords: Food intake, Echocardiography, Myocardial performance index
\end{abstract}

\section{Background}

Myocardial performance index (MPI), also known as Tei-index, was introduced by Tei in 1995 as a Dopplerderived index of combined systolic and diastolic myocardial performance [1]. MPI is defined as the sum of isovolumetric contraction time (ICT) and isovolumetric relaxation time (IRT) divided by ejection time (ET) (Fig. 1). MPI has been examined in many studies in a variety of populations over the last two decades, and has been used as a measure of total left ventricular function. It has been used for prognostic examinations of patients regarding heart failure [2], acute myocardial infarction [3] and heart transplants [4], as well as in healthy athletes [5] and in yoga practitioners with heart failure [6]. MPI has also been used in several studies regarding pediatric patients; for example helping to detect acute cellular rejection after heart transplant [7], for early detection of chemo-induced cardiotoxicity [8], in investigations concerning cardiovascular changes in children with bicuspid aortic valves [9], and for assessment of ventricular function in obese children [10].

\footnotetext{
* Correspondence: ylva.gardinger@skane.se

'Department of Translational medicine, Unit of Clinical Physiology and

Nuclear Medicine, Skåne University Hospital, Lund University, Malmö, Sweden

${ }^{2}$ Department of Translational medicine, Unit of Radiology, Skåne University

Hospital, Lund University, Malmö, Sweden

Full list of author information is available at the end of the article
}

Digestion of food is known to significantly alter hemodynamics [11-13], and may therefore affect MPI, as loading conditions are altered. We have previously reported data from our cohort on the effect of food intake on systolic and diastolic function [14-16]. The purpose of the present study is to evaluate the hypothesis that food intake, in healthy volunteers, may have an effect on myocardial performance index, as it is considered a reflection of the total left ventricular function. To our knowledge this has not been investigated previously.

\section{Methods \\ Study population}

Study subjects were 23 healthy volunteers (11 male and 12 female aged $25.6 \pm 4.5$ years]. No subjects had symptoms or history of cardiovascular disease or any other chronic diseases. None of the subjects were taking cardiovascular medication. Other exclusion criteria were inappropriate acoustic windows and non-sinus rhythm.

\section{Procedures}

The examinations were performed in the morning after fasting overnight. A baseline echocardiographic exam was performed, after which the subjects ingested a standardized meal consisting of $300 \mathrm{~g}$ rice pudding (AXA 


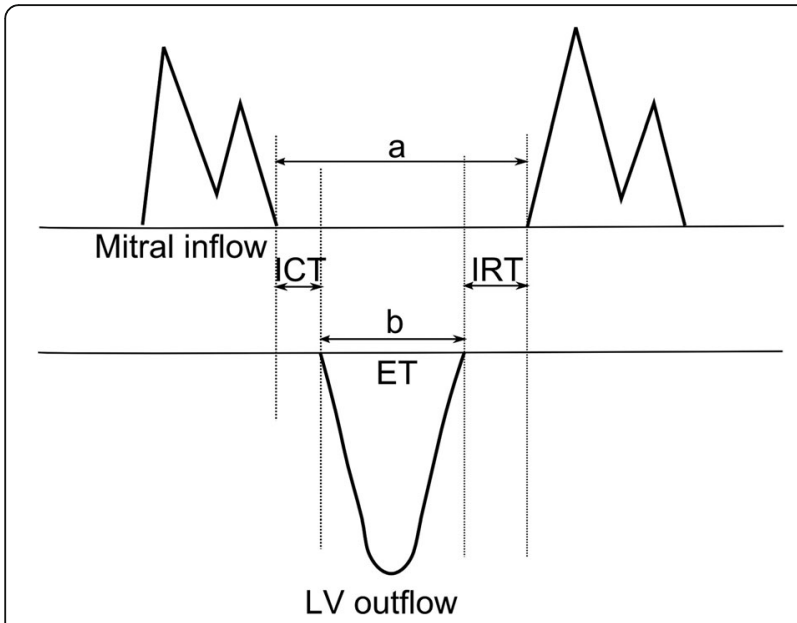

Fig. 1 Schematic figure of measurement and calculation of myocardial performance index

Goda Gröten Risgrynsgröt; Lantmännen AXA, Järna Sweden). A second echocardiographic exam was performed $30 \mathrm{~min}$ after, and a third exam $110 \mathrm{~min}$ after the meal. The subjects reassumed a supine position between the echocardiographic examinations.

\section{Echocardiography}

After an initial screening examination to rule out cardiac dysfunction, a transthoracic echocardiographic examination was performed in left lateral position, with Sonos 5500 (Philips, Andover, MA, USA) before, $30 \mathrm{~min}$ after, and $110 \mathrm{~min}$ after the meal, in each instance after a 15 min rest. A single observer performed all echocardiographic measurements three times on separate cardiac cycles, from which the mean value was derived.

The pulsed Doppler parameters were acquired from the apical four-chamber view, with the sample volume for the signal of the mitral inflow velocity pattern at the tip of the mitral leaflets, and the left ventricular outflow velocity was recorded with the sample volume positioned just below the aortic annulus. Ejection time (ET) was measured as the duration of ventricular outflow. Isovolumetric contraction time (ICT) + isovolumetric relaxation time (IRT) were obtained by subtracting ET from the interval between mitral closure to opening (Fig. 1).

\section{Statistical analysis}

Data are presented as mean \pm standard deviation (SD). Statistical analyses were performed using Statistica 7.1 (StatSoft Inc, Tulsa, OK, USA). Comparisons between fasting values for ICT, IRT, ET and MPI versus values 30 and $110 \mathrm{~min}$ after the ingestion of food, were analyzed for significance with Wilcoxon matched pairs test. Statistical significance was set at a level of $P<0.05$.

\section{Results}

All subjects had complete measurements, and no subjects were found to have any cardiac dysfunction. Table 1 summarizes the baseline echocardiography findings. The mean value for MPI decreased significantly $30 \mathrm{~min}$ after food intake, and had almost returned to baseline value 110 min after eating. MPI in these young, healthy volunteers decreased from fasting value $0.28 \pm 0.06-0.20 \pm$ $0.0730 \mathrm{~min}$ after eating $(P<0.05)$, and was with an index value of $0.26 \pm 0.06$ almost back to baseline value after $110 \mathrm{~min}(P=0.15)$ (Fig. 2). More specifically the sum of ICT + ET + IRT decreased from $0.400 \pm 0.024 \mathrm{~ms}$ fasting to $0.370 \pm 0.030 \mathrm{~ms}(P<0.001) 30 \mathrm{~min}$ after food intake, and to $0.391 \pm 0.023 \mathrm{~ms}(P<0.05)$ after $110 \mathrm{~min}$. The change in ET, on the other hand, was a slight decrease from fasting value $0.313 \pm 0.016 \mathrm{~ms}$ to 0.309 $\pm 0.016 \mathrm{~ms}(P<0.05) 30 \mathrm{~min}$ after eating, and $0.311 \pm$ $0.016 \mathrm{~ms}$ (NS) $110 \mathrm{~min}$ after food intake. Table 2 summarizes the effect of food intake on blood pressure, heart rate, MPI and selected systolic and diastolic parameters which have been reported earlier [16], but are included for comparison.

\section{Discussion}

This study shows that myocardial performance index is affected by food intake in healthy subjects. Since hemodynamics are known to change postprandially, it is not unreasonable to assume that MPI would be altered accordingly. Although there was a small decrease in ejection time, the main alteration leading to the significant decrease in MPI after eating is the decrease in ICT + IRT. In comparison to our previous findings [14-16] the change in MPI is larger than the changes seen for

Table 1 Subjects' anthropometric characteristics and cardiac dimensions $(n=23)$

\begin{tabular}{ll}
\hline Variable & \\
\hline Sex $($ male/female) & $11 / 12$ \\
Weight $(\mathrm{kg})$ & $68 \pm 11$ \\
Height $(\mathrm{cm})$ & $177 \pm 8$ \\
BMI $\left(\mathrm{kg} / \mathrm{m}^{2}\right)$ & $21.7 \pm 2.2$ \\
BSA $\left(\mathrm{m}^{2}\right)$ & $1.8 \pm 0.2$ \\
LVIDd $\left(\mathrm{mm} / \mathrm{m}^{2}\right)$ & $26.7 \pm 1.9$ \\
LVIDs $\left(\mathrm{mm} / \mathrm{m}^{2}\right)$ & $17.7 \pm 1.9$ \\
IVSd $\left(\mathrm{mm} / \mathrm{m}^{2}\right)$ & $5.1 \pm 0.4$ \\
PWTd $\left(\mathrm{mm} / \mathrm{m}^{2}\right)$ & $5.0 \pm 0.4$ \\
LA $\left(\mathrm{mm} / \mathrm{m}^{2}\right)$ & $18.2 \pm 1.9$ \\
LVM $\left(\mathrm{g} / \mathrm{m}^{2}\right)$ & $87.6 \pm 18.1$ \\
\hline Ab
\end{tabular}

Abbreviations: Indexed for BSA: LVIDd left ventricular internal dimension in diastole, LVIDs left ventricular internal dimension in systole, IVSd interventricular septum thickness in diastole, PWTd posterior wall thickness in diastole, $L A$ left atrial end-systolic diameter, and $L V M$ left ventricular mass, $B S A$ Body surface area

Values are mean $\pm S D$ 


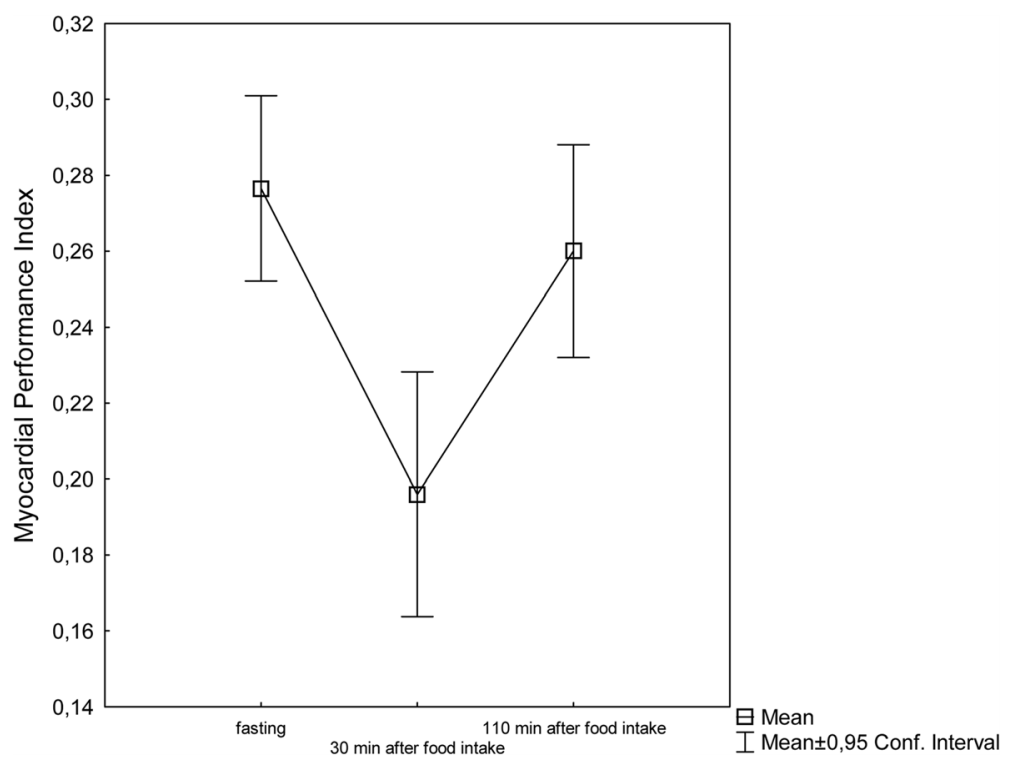

Fig. 2 Myocardial performance index (MPI) before (MPI 1), 30 min after (MPI 2,P<0.05), and 110 min after the meal (MPI 3,P=0.15)

Table 2 Description of hemodynamics, blood pressure, heart rate, MPI and and selected systolic and diastolic parameters before, 30 and 110 min after a standardized meal $(n=23)$

\begin{tabular}{|c|c|c|c|c|}
\hline Variable & Fasting & 30 min after food intake & 110 min after food intake & $\begin{array}{l}\text { Percent change fasting } \\
\text { versus } 30 \text { min (\%) }\end{array}$ \\
\hline MPI left ventricle & $0.28 \pm 0.06$ & $0.20 \pm 0.07^{* * *}$ & $0.26 \pm 0.06$ & -29 \\
\hline Heart rate (bpm) & $60 \pm 8$ & $64 \pm 10^{* *}$ & $60 \pm 10$ & 7 \\
\hline Systolic BP (mm hg) & $103 \pm 9$ & $102 \pm 10$ & $102 \pm 9$ & -1 \\
\hline Diastolic BP (mm hg) & $66 \pm 7$ & $58 \pm 7^{* *}$ & $63 \pm 6^{*}$ & -12 \\
\hline $\mathrm{SV}(\mathrm{ml})$ & $66 \pm 13$ & $79 \pm 16^{* * *}$ & $70 \pm 13^{* *}$ & 20 \\
\hline $\mathrm{CO}(\mathrm{ml} / \mathrm{min})$ & $3948 \pm 831$ & $5058 \pm 1087^{* * *}$ & $4110 \pm 756$ & 28 \\
\hline$E(\mathrm{~cm} / \mathrm{s})$ & $81.6 \pm 13.2$ & $88.1 \pm 14.5^{* *}$ & $81.0 \pm 13.0$ & 8 \\
\hline$A(\mathrm{~cm} / \mathrm{s})$ & $44.3 \pm 8.4$ & $51.0 \pm 10.6^{* *}$ & $46.9 \pm 7.7$ & 15 \\
\hline$E / A$ & $1.9 \pm 0.4$ & $1.8 \pm 0.4$ & $1.8 \pm 0.4$ & -5 \\
\hline DT (msec) & $191 \pm 21$ & $162 \pm 20^{* * *}$ & $177 \pm 17^{*}$ & -15 \\
\hline $\mathrm{s}^{\prime}$ (septal) $(\mathrm{cm} / \mathrm{s})$ & $8.3 \pm 0.9$ & $9.5 \pm 1.2^{* * *}$ & $9.3 \pm 1.1^{* * *}$ & 14 \\
\hline $\mathrm{s}^{\prime}$ (lateral) $(\mathrm{cm} / \mathrm{s})$ & $12.4 \pm 2.2$ & $13.8 \pm 2.1^{* *}$ & $13.0 \pm 2.3$ & 11 \\
\hline $\mathrm{e}^{\prime}($ septal) $(\mathrm{cm} / \mathrm{s})$ & $12.6 \pm 2.0$ & $13.0 \pm 2.2$ & $13.3 \pm 2.6$ & 3 \\
\hline $\mathrm{e}^{\prime}$ (lateral) $(\mathrm{cm} / \mathrm{s})$ & $19.7 \pm 4.7$ & $21.1 \pm 4.0$ & $19.2 \pm 3.6$ & 7 \\
\hline E/e' (septal) & $6.6 \pm 1.3$ & $6.9 \pm 1.3$ & $6.3 \pm 1.4$ & 5 \\
\hline E/e' (lateral) & $4.3 \pm 0.9$ & $4.3 \pm 0.8$ & $4.3 \pm 0.9$ & 0 \\
\hline E/e' (average) & $5.1 \pm 0.9$ & $5.2 \pm 0.8$ & $5.0 \pm 0.9$ & 2 \\
\hline
\end{tabular}

Abbreviations: MPI Myocardial performance index, BP Blood pressure, SV left ventricular stroke volume, $C O$ left ventricular cardiac output, $E$ Peak of early diastolic mitral flow velocities, $A$ late diastolic mitral flow velocities. DT Deceleration time of E-wave, $s^{\prime}$ Pulsed Tissue Doppler imaging velocities: peak systolic diastolic velocities, $e^{\prime}$ Pulsed Tissue Doppler imaging velocities: early diastolic velocities

*Indicates significant difference $(P<0.05)$, compared to fasting values

** Indicates significant difference $(P<0.01)$, compared to fasting values

${ }^{* * *}$ Indicates significant difference $(P<0.001)$, compared to fasting values

Values are mean $\pm S D$. Last column shows percent change for the different values, fasting versus 30 min after food intake 
diastolic parameters, and of the same magnitude as several systolic changes. The exact mechanisms behind the findings in the present investigation are hard to define. Several kinds of postprandial cardiovascular changes have, however, been reported in the literature. It has been suggested that the increase in postprandial cardiac output is the result of increases in bloodflow in the superior mesenteric artery, the heart rate and stroke volume [13]. The correlation between heart rate and MPI has however been found to be insignificant [1] or weak [17]. Physiological changes in the levels of glucose, insulin, glucagon-like peptide 1 (GLP-1) and ghrelin may also influence the activity of the heart [18]. Moreover, it is known that insulin has positive chronotropic and inotropic effects on the heart [19], and the hormone GLP-1 has been shown to improve left ventricular function $[20,21]$. The hormone ghrelin has been shown to increase cardiac output (CO) and stroke volume (SV) [22-24]. The ingestion of food has also been shown to decrease the diastolic blood pressure [18]. Considering the changes in hemodynamics with increased cardiac output and altered loading conditions it is not surprising that MPI - and more specifically the isovolumetric contraction and relaxation - changes accordingly.

Myocardial performance index has been used to investigate different populations, such as patients with heart failure [2], acute myocardial infarction [3], heart transplants [4], COPD [25], patients with chronic ischemic cardiomyopathy who have undergone revascularization [26], as well as in healthy young men during high altitude exposure [27]. MPI has also been investigated in relation to age [28].

The time frames between food intake and echocardiographic examinations have, however, not been specified in these studies, suggesting that these were not controlled. While it is difficult to control patients' food intake in clinical echocardiography, one should be aware of the effect that food intake has on this echocardiographic parameter. The influence of food consumption should be considered in studies, especially when a small sample size is involved.

This investigation was limited by our inability to perform the echocardiographic exams blinded to the state of food intake, because a single observer performed all exams. In an attempt to avoid bias, all exams were stored digitally and the measurements were performed later in random order. The change in MPI had not yet returned to baseline values $110 \mathrm{~min}$ after food intake, and in hindsight we would have chosen a longer time period. Moreover, we did not include a control group who did not receive the prepared meal after overnight fasting. The present study shows the effect of food intake only in young, healthy subjects. Additional studies are warranted in older healthy subjects and in patients with various health conditions to determine whether the findings in the present study are reproducible in such populations.

\section{Conclusions}

This study shows that myocardial performance index is affected by food intake in healthy subjects.

\begin{abstract}
Abbreviations
A: Late diastolic mitral flow velocities; BP: Blood pressure; CO: Left ventricular cardiac output; DT: Deceleration time of E-wave; E: Peak of early diastolic mitral flow velocities; e': Pulsed Tissue Doppler imaging velocities: early diastolic velocities; ET: Ejection time; GLP-1: Glucagon-like peptide 1; ICT: Isovolumetric contraction time; IRT: Isovolumetric relaxation time; MPI: Myocardial performance index; s': Pulsed Tissue Doppler imaging velocities: peak systolic diastolic velocities; SD: Standard deviation; SV: Left ventricular stroke volume

\section{Acknowledgements}

Not applicable.

\section{Funding}

Financial support for this study was received from the Hulda and Conrad Mossfelt Foundation, the Swedish Heart and Lung Association, the Swedish Society of Medicine, the Gyllenstierna Krapperup's Foundation and grants from Lund University, Skåne University Hospital and Region Skåne.
\end{abstract}

Availability of data and materials

Please contact author for data requests.

\section{Authors' contributions}

The authors' contributions were as follows: All authors designed the study. JH was responsible for recruiting the subjects. MD performed the echocardiographic examinations. YG and MD carried out the statistical calculations. YG wrote the first draft of the manuscript, and all authors made critical revisions of the manuscript. All authors read and approved the final manuscript.

\section{Competing interests}

The authors declare that they have no competing interests.

Consent for publication

Not applicable.

Ethics approval and consent to participate

Written informed consent was obtained from all subjects. The study was approved by the Regional ethics committee, Lund, Sweden.

\section{Publisher's Note}

Springer Nature remains neutral with regard to jurisdictional claims in published maps and institutional affiliations.

\section{Author details}

${ }^{1}$ Department of Translational medicine, Unit of Clinical Physiology and Nuclear Medicine, Skåne University Hospital, Lund University, Malmö, Sweden. ${ }^{2}$ Department of Translational medicine, Unit of Radiology, Skåne University Hospital, Lund University, Malmö, Sweden. ${ }^{3}$ Department of Clinical Sciences, Division of Medicine, Skåne University Hospital, Lund University, Malmö, Sweden.

Received: 11 October 2016 Accepted: 29 March 2017 Published online: 05 April 2017

\section{References}

1. Tei C, Ling LH, Hodge DO, Bailey KR, Oh JK, Rodeheffer RJ, Tajik AJ, Seward JB. New index of combined systolic and diastolic myocardial performance: a simple and reproducible measure of cardiac function - a study in normal and dilated cardiomyopathy. J Cardiol. 1995;26:357-66.

2. Ärnlöv J, Ingelsson E, Risérus U, Berglund L, Lithell H. A Doppler-derived index of combined left ventricular systolic and diastolic function is an 
independent predictor of cardiovascular mortality in elderly men. Am Heart J. 2004;25:2220-5.

3. Poulsen SH, Jensen SE, Nielsen JC, Møller JE, Egstrup K. Serial changes and prognostic implications of a Doppler-derived index of combined left ventricular systolic and diastolic myocardial performance in acute myocardial infarction. Am J Cardiol. 2000;85:19-25.

4. Frea S, Capriolo M, Bergamasco L, lacovino C, Quaglia FC, Ribezzo M, Marra WG, Boffini M, Rinaldi M, Morello M, Gaita F. Prognostic role of myocardial performance index on long-term survival after heart transplantation: a prospective study. Echocardiography. 2013;30:1033-41.

5. Tuzun N, Ergun M, Alioglu E, Edem E, Tengiz I, Aytemiz F, Ercan E, Islegen C. TEl index in elite sprinters and endurance athletes. I Sports Med Phys Fitness. 2015:55(9):988-94.

6. Krishna BH, Pal P, Pal G, Balachander J, Jayasettiaseelon E, Sreekanth Y, Sridhar M, Gaur G. A randomized controlled trial to study the effect of yoga therapy on cardiac function and N terminal Pro BNP in heart failure. Integr Med Insights. 2014;9:1-6.

7. Flanagan R, Cain N, Tatum G, DeBrunner M, Drant S, Feingold B. LV MPI change for detection of acute cellular rejection in pediatric heart transplantation. Pediatr Transplant. 2013;17:782-6.

8. Ruggiero A, De Rosa G, Rizzo D, Leo A, Maurizi P, De Nisco A, Vendittelli F, Zuppi C, Mordente A, Riccardi R. Myocardial performance index and biochemical markers for early detection of doxorubicin-induced cardiotoxicity in children with acute lymphoblastic leukaemia. Int J Clin Oncol. 2013;18:927-33.

9. Hanedan Onan S, Baykan A, Sezer S, Narin F, Mavili E, Baykan Z, Uzum K, Narin N. Evaluation of cardiovascular changes in children with BAVs. Pediatr Cardiol. 2016;37:472-81.

10. Levent E, Göksen D, Ozyurek AR, Darcan S, Coker M. Usefulness of the myocardial performance index (MPI) for assessing ventricular function in obese pediatric patients. Turk J Pediatr. 2005;47:34-8.

11. Fagan TC, Sawyer PR, Gourley LA, Lee JT, Gaffney TE. Postprandial alterations in hemodynamics and blood pressure in normal subjects. Am J Cardiol. 1986;58:636-41.

12. Waaler BA, Eriksen M, Janbu T. The effect of a meal on cardiac output in man at rest and during moderate exercise. Acta Physiol Scand. 1990;140:167-73.

13. Waaler BA, Eriksen M, Toska K. The effect of meal size on postprandial increase in cardiac output. Acta Physiol Scand. 1991;142:33-9.

14. Dieden A, Gårdinger Y, Hlebowicz J, Björgell O, Dencker M. Effect of food intake on left and right ventricular systolic tissue Doppler measurements. Clin Physiol Funct Imaging. 2016;36:396-400.

15. Gårdinger Y, Hlebowicz J, Björgell O, Dencker M. Effect of food intake on left ventricular wall stress. Cardiovasc Ultrasound. 2014;12:2.

16. Dencker $\mathrm{M}$, Björgell $\mathrm{O}$, Hebowicz J. Effect of food intake on commonly used pulsed doppler and tissue doppler measurements. Echocardiography. 2011:28:843-7.

17. Poulsen SH, Nielsen JC, Andersen HR. The influence of heart rate on Doppler-derived myocardial performance index. J Am Soc Echocardiography. 2000;13:379-84.

18. Hebowicz J, Lindstedt S, Björgell O, Dencker M. The effect of endogenously released glucose, insulin, glucagon-like peptide 1, ghrelin on cardiac output, heart rate, stroke volume and blood pressure. Cardiovascular Ultrasound. 2011;9:43.

19. Baron AD. Hemodynamic actions of insulin. Am J Physiol. 1994:267:187-202.

20. Nikolaidis LA, Mankad S, Sokos GG, Miske G, Shah A, Elahi D, Shannon RP. Effects of glucagon-like peptide-1 in patients with acute myocardial infarction and left ventricular dysfunction after successful reperfusion. Circulation. 2004;109:962-25.

21. Sokos GG, Nikolaidis LA, Mankad S, Elahi D, Shannon RP. Glucagon-like peptide-1 infusion improves left ventricular ejection fraction and functional status in patients with chronic heart failure. J Card Fail. 2006;212:694-9.

22. Nagaya N, Kojima M, Uematsu M, Yamagishi M, Hosoda H, Oya H, Hayashi $Y$, Kanawa K. Hemodynamic and hormonal effects of human ghrelin in healthy volunteers. Am J Physiol Regul Integr Comp Physiol. 2010;280:1483-7.

23. Nagaya N, Miyatake K, Uematsu M, Oya H, Shimizu W, Hosoda H, Kojima M, Nakanishi N, Mori H, Kangawa K. Hemodynamic, renal, and hormonal effects of ghrelin infusion in patients with chronic heart failure. J Clin Endocrinol Metab. 2010;86:5854-9.

24. Nagaya N, Moriya J, Yasumura Y, Uematsu M, Ono F, Shimizu W, Ueno K Kitakaze M, Miyatake K, Kangawa K. Effects of ghrelin administration on left ventricular function, exercise capacity, and muscle wasting in patients with chronic heart failure. Circulation. 2004;110:3674-9.

25. Escande W, Duva Penthia A, Coisne A, Mouton S, Richardson M, Polge AS, Ennezat PV, Tillie-Leblond I, Montaigne D. Left Ventricular myocardial performance index predicts poor outcome during COPD exacerbation. Int J Cardiol. 2014;173:575-9.

26. Carluccio E, Biagoli P, Alunni G, Murrone A, Zuchi C, Biscottini E, Lauciello R, Pantano P, Gentile F, Nishimura R, Ambrosio G. Improvement of myocardial performance (Tei) index closly reflects intrinsic improvement of cardiac function: assessment in revascularized hibernating myocardium. Echocardiography. 2012;29:298-306.

27. Rao M, Li J, Zhang J, Gao X, Yu S, Yu J, Chen G, Xu B, Li H, Rao R, Huang L, Jin J. Left ventricular function during acute high-altitude exposure in a large group of healthy young Chinese Men. PLoS ONE. 2015;10:e0116936.

28. Vancheri $F$, Vancheri $S$, Henein M. Effect of age on left ventricular global dyssynchrony in asymptomatic individuals. Echocardiography. 2016;00:1-7.

\section{Submit your next manuscript to BioMed Central and we will help you at every step:}

- We accept pre-submission inquiries

- Our selector tool helps you to find the most relevant journal

- We provide round the clock customer support

- Convenient online submission

- Thorough peer review

- Inclusion in PubMed and all major indexing services

- Maximum visibility for your research

Submit your manuscript at www.biomedcentral.com/submit
Biomed Central 